\title{
Crimes Related to Human Trafficking: Nature, Parameters, Legislative Counter Tools
}

\author{
Alimzhan Baurzhanovich Bekmagambetov ${ }^{1}$ \\ ${ }^{1}$ Federal State Institution of Higher Professional Education, "Chelyabinsk State University" Kostanay Branch, \\ Kazakhstan \\ Correspondence: Alimzhan Baurzhanovich Bekmagambetov, Federal State Institution of Higher Professional \\ Education, "Chelyabinsk State University" Kostanay branch, Borodina Street, 168a, 110000, Kostanay, \\ Kazakhstan.
}

Received: October 29, 2014 Accepted: December 20, 2014 Online Published: March 16, 2015

doi:10.5539/ass.v11n7p152 URL: http://dx.doi.org/10.5539/ass.v11n7p152

\begin{abstract}
The article deals with current issues of studying the nature of a complex, multifaced phenomenon, criminological measuring of its quantitative and qualitative parameters, elaboration of the most optimal legislative formulas (disposition of criminal law on the definition of the "human trafficking" concept). Attention is drawn to the fact that there are corresponding basic laws in the national legal system for similar complex socio-legal phenomena (organized crime, terrorism, drug addiction, corruption).
\end{abstract}

Keywords: human trafficking, legal nature, countermeasure policy, basic law

\section{Introduction}

Since gaining independence, the Republic of Kazakhstan follows the course of constructing a secular, social, legal, democratic state, which indicates the dialectics and relevance of the development identity and taking into account international standards. Certain successes and achievements, including innovations and initiatives, ambitious plans and invaluable experience play an important role as well.

Nuclear disarmament, the traditional congress of world religious leaders, the chairmanship in the OSCE, the right to host the EXPO 2017 and this list is constantly updating.

In high-speed mode, the most ambitious projects in the economic, political and legal spheres are intensively implemented, the effect of which proves a gradual improvement in the quality of life of millions of people of Kazakhstan.

Of course, there is always a potential for improving the above-mentioned processes, especially in regard to solving problems that require coordinated efforts at the international level.

They will include issues of combating human trafficking, which necessitates the theoretical study of such problems as the nature (essence), the doctrinal (sociological, economic, geographical, criminological, criminal law, criminal procedure, forensic) analysis of constitutive and the other most significant for science and practices attributes and parameters.

\section{Research Methods}

The basis for the research methods and the corresponding obtained results was a set of different successfully tested general scientific and specialized scientific research methods: the formal-logical and systematic structural analysis, comparative, constructively critical review of special studies (domestic and foreign theoretical literature).

\section{Results}

\subsection{On Analyzing the Nature of the Phenomenon under Study}

The author reviewed abstracts of theses (24) defended in Russia and Kazakhstan for the last 10 years on the problem under study (Akimov, Bekmagambetov, Buryak, Hetman, Gorban, Gromov, Dushko, Egorova, Zhinkin, etc.), 54 issues of the Bulletin of the Supreme Court of the Republic of Kazakhstan on criminal law enforcement for human trafficking. In order to correlate with the general criminal political course we traced relationship with 
the modernization processes of anti-crime legislation and studied publications of Kazakhstanian (Akimzhanov, Dzhansaraeva, Dzhekebaev, Mizanbaev, Moldabaev, etc.) and Russian scientists (Babaev, Kozachenko, Naumov, Revin, etc.).

It's not a coincidence that many experts emphasize the complex multidimensional nature of this phenomenon. Problems of anti-trafficking are the subject of special researches for more than 10 years in Russia and Kazakhstan, and not only in criminal law and criminology (18 of 24 theses), but also in Criminal Procedure and Criminology (3 of 24), Political Science ( 1 of 24), sociology ( 1 of 24) and even geography ( 1 of 24). And this is without taking into account a large body of scientific publications, study guides and monographs. These figures are quite informative and revealing. This is confirmed by references to the works of prominent foreign researchers.

The director of the Center of the Organized Crime study, Dr. Louise I. Shelley, focuses on the relationship between human trafficking and transnational crimes in a number of publications.

In this context, the following quote of the above mentioned author is of particular interest: Transnational crime will be a defining issue of the 21st century for policymakers - as defining as the Cold War was for the 20th century and colonialism was for the 19th. Terrorists and transnational crime groups will proliferate because these crime groups are major beneficiaries of globalization. They take advantage of increased travel, trade, rapid money movements, telecommunications and computer links, and are well positioned for growth (Shelley).

The researchers Donna M. Hughes and Siddharth Kara focus on human trafficking for sexual exploitation.

Siddharth Kara in his book rightly notes: That slavery still exists may surprise some readers but the practice of violently coerced labor continues to thrive in every corner of the globe. There were 28.4 million slaves in the world at the end of 2006 and there will most likely be a greater number by the time you read this book (Siddharth, 2009, p. IX, preface).

Donna M. Hughes conducts a historical excursus on how human trafficking was born in the post-Soviet countries, and notes that In the Soviet Union, a shadow economy, often controlled by government officials, existed for decades to meet the needs of the people for goods and services. When the Soviet Union collapsed, the shadow economy networks expanded to become transnational criminal networks that increasingly operate beyond the reach of law enforcement in any one state, and more ominously, operate in cooperation with law enforcement and government officials in some states (Hughes, 2000).

In its turn, as rightly pointed out in the Message from the Chief of Mission: We live in an age of unprecedented human mobility. Migration is considered one of the defining global issues of the early twenty-first century, with more and more people on the move today than at any other point in history. In Central Asia, which has been a crossroads of goods and people from the days of the Silk Road, hundreds of thousands of people move daily across the international borders in search of employment and opportunity. Millions of Central Asians work abroad and remit funds to their families (Keserovic).

Since obtaining his Ph.D. degree in 2005 and to date the author of this publication conducts multi-faceted research within the framework of which published two monographs (in Kazakhstan and Germany) (Bekmagambetov, 2012), published more than 20 scientific articles in peer-reviewed journals of Kazakhstan and Russia, as a chairman of the Scientific and Production Establishment made a report at the OSCE review conference (Kazakhstan, Astana, 27 November 2010), participated in the international seminar on human rights in Kazakhstan and Germany (Kazakhstan \& Schuchinsk, 2010, July 4-5), in line with the Gosinform order he implemented an important social project to prevent trafficking of young people, expressed an expert opinion on the implementation of international standards and passed it on to the Administration of the President of the Republic of Kazakhstan.

In particular, in the monograph published in Germany we wrote the following: "The development of legislative policy on combating human trafficking at the present stage should be a two-level one, as in the case with counter-terrorism, extremism, drug addiction. The first level includes basic legislation (laws against terrorism, extremism and drug addiction, etc.), the second - criminal law provisions that provide evidence of a crime" (Bekmagambetov, 2012, pp. 144-145).

And this is the essence of our many specific elaborations and the basis for their practical implementation, but first of all it is important to explore the essence of the phenomenon, to know its nature.

The essence of any criminal phenomenon has its quantitative measurement, in which the figure of zero may indicate a lot. 
According to the Prosecutor General of the Republic of Kazakhstan A. Daulbaeva, about 600 victims of human trafficking have been identified over the past five years in Kazakhstan. Law enforcement authorities found nearly 1.5 thousand crimes related to human trafficking, more than 800 people have been convicted. Each year about 300 crimes is registered in this category (2013).

In addition, only during a three-year period (starting from 2010) from the total number (820) of the criminal cases related to human trafficking, the investigation of 453 cases has been completed, 360 criminal cases have been handed to the court, 93 criminal cases have been dismissed on the exculpatory grounds. And finally, the comparative analysis of the statistical data on crimes related to human trafficking for the first 9 months of 2013 in comparison with the crime indicators of this type in the CIS countries is rather interesting.

Statistical data in absolute figures is as follows (kidnapping, unlawful imprisonment, human trafficking, slave labour) (Analysis of the statistical data, p. 4).

Table 1.

\begin{tabular}{cccc}
\hline \# s.p. & Country & total & increase/reduction \\
\hline 1 & The Russian Federation & 764 & -14.3 \\
2 & The Republic of Uzbekistan & 498 & 9.2 \\
3 & The Republic of Kazakhstan & 416 & 108.0 \\
4 & The Republic of Ukraine & 387 & 15.9 \\
5 & The Republic of Azerbaijan & 153 & 10.9 \\
6 & The Republic of Moldova & 130 & -12.8 \\
7 & The Republic of Armenia & 48 & 33.3 \\
8 & The Republic of Tajikistan & 44 & 144.4 \\
9 & The Kyrgyz Republic & 39 & -15.2 \\
10 & The Republic of Belarus & 35 & 169.2 \\
\hline
\end{tabular}

The above information indicates that the country accumulates certain law enforcement practice in this category of cases, which needs further improvement, including taking into account such factor as the latency of crimes related to human trafficking.

It only becomes a subject of analytical materials of the Compliance Criminal Division of the Supreme Court of the Republic of Kazakhstan. Contents of the Bulletin of the Supreme Court for the period from 2009 to 2014 (54 issues) enabled us to find only one material of interest - Review of Jurisprudence (including the practice of sentencing) in criminal cases involving offenses against family and minors. It does not contain information on the issue of human trafficking, with the exception of two examples of the involvement of minors in prostitution (art.133-2 of the Criminal Code) (Review of court practice, 2013, pp. 56-70). In this case, as representatives of the supreme legislative body of the country rightly note, in particular Bychkov S., "Most of the criminal cases brought before a court in connection with identification of human trafficking cases are not classified according to Art.128 "Human trafficking "and "Trafficking of minors", but under Art. 271 of the Criminal Code of the Republic of Kazakhstan "Organization or running brothels for prostitution and pimping" (Bychkova, 2012, p. 6). This is confirmed by analytical materials repeatedly cited in this publication of the Prosecutor General's Office of Kazakhstan, the International Migration Organization in Kazakhstan, numerous publications in the media, content analysis, which is carried out by us on an ongoing basis. We can predict that this point will also be found in the future in the relevant reviews of the Supreme Court of the Republic of Kazakhstan. Concerning objective criminological measuring, and hence correct identification of human trafficking, ultimately the rule of law and justice, it is important to improve measures to overcome or to at least minimize such factor as latency. In this regard, the recommendation contained in the Needs Assessment Toolkit on the Criminal Justice Response to Human Trafficking is relevant: The desk review has to be performed in a comprehensive way due to the complex nature of the phenomenon of trafficking in persons. It is believed that the incidence of trafficking in persons is underreported due to the clandestine nature of the crime (Needs Assessment Toolkit, p. 6).

Thus, at the initial stage the results of the integrated multidisciplinary research in the form of optimal conceptual quintessence relevant to the true essence of the phenomenon under examination, it should be reflected in the legislative, law enforcement and advocacy processes.

At the same time, we must resolve the dual task - taking into account international standards of the United Nations and local peculiarities (politics, law, mentality). In particular, this is indicated in the introduction of Model Law against Trafficking in Persons: The Model Law will both facilitate and help systematize provision of 
legislative assistance by UNODC as well as facilitate review and amendment of existing legislation and adoption of new legislation by States themselves. It is designed to be adaptable to the needs of each State, whatever its legal tradition and social, economic, cultural and geographical conditions (Model Law against Trafficking in Persons, p. 1).

\subsection{On the Legislative Counter Tools}

In order to comply with the UN standards and in particular with its Convention, the international community today has gained invaluable experience in the field of combating human trafficking, which is common in many states. The main "trendsetter" in this process is the UN, which seems to take into account productive elaborations of the Transnational Organized Crime researchers.

We note immediately that in our opinion, that we proved in the series of our publications in Kazakhstan, it is necessary to model binary (two-level) system of legal tools in the field of combating human trafficking. Criminalization of acts related to human trafficking, as we know, is carried out in the framework of criminal law regulation by registering them in the corresponding norms, prohibitions of the Criminal Code. Any other questions, and it is a very extensive formation, should be reflected in a special basic law on combating human trafficking. And what do we have now? First - the norms of the Criminal Code on human trafficking and acts related to it (On action plan, 2012). Secondly, "On action plan of the government of the Republic of Kazakhstan for 2012-2014 directed at combating and preventing crimes related to trafficking in human beings", "Decree \#1347 of the government of the Republic of Kazakhstan dated October 24, 2012" with the aim, comprising 40 items (Normative Resolution, 2012). And finally, the Normative Resolution of the Supreme Court of the Republic of Kazakhstan dated December 29, 2012 \#7 "On application of legislation determining liability for trafficking in human beings (Informational system Paragraph).

In the Criminal Code of Kazakhstan initially there were two norms: article 128 "Recruitment of people for exploitation", art.133 "Trafficking of minors", in respect of which in law and practice of human rights the phrase "crime (crime) associated (connected) to trafficking" is still actively used.

The phrase "crime (option - crime) associated (linked) with human trafficking" in the national criminal legislation of Kazakhstan has appeared relatively recently and has received only schematic (mainly in terms of numbers) designation.

So, the footnote to Article 128 of the Criminal Code of the Republic of Kazakhstan (Criminal Code, 1997) provides that offenses related to human trafficking are recognized as offenses provided in Article 113 of the Criminal Code of the Republic of Kazakhstan (coercion to seizure or to unlawfully remove human organs and tissues), paragraph b) of the third part of Article 125 of the Criminal Code of the Republic of Kazakhstan (kidnapping for the purpose of exploitation) a), paragraph b) of the third part of Article 126 of the Criminal Code of the Republic of Kazakhstan (illegal deprivation of liberty for the purpose of exploitation), Articles 128 (human trafficking), 132-1 of the Criminal Code (involving a minor into prostitution), 133 of the Criminal Code (trafficking of minors), 270 (involving into prostitution) and 271 (organization or maintenance of dens for prostitution and pimping).

In this regard, it is reasonable to question the interpretation of this concept. The Criminal Code does not contain the corresponding expanded definition (authentic interpretation). Simple listing of articles with no explanation of their grouping logic does not count. None of the required information (definitions) and in the above inter-agency plan, nor in the previously mentioned act of forensic normative interpretation.

As Kozachenko I., Avdeeva E. correctly noted legislative regulation of the human trafficking formula, providing accurate legal assessment of an implemented socially dangerous unlawful act provided for in the criminal law is appropriate. The most acceptable proposal is to improve ... standards taking into account the etymological meaning of the used terms (Kozachenko \& Avdeeva, 2012, p. 65).

The meaning of the Normative Resolution of the Supreme Court of the Republic of Kazakhstan dated December 29, $2012 \# 7$ "On application of legislation determining liability for trafficking in human beings" is difficult to overestimate, especially since this event is a single chain of actively and consistently undertaken amendments of the criminal law and the formation of a uniform judicial and investigative practice in recent years. In this light A. Mizanbaev's words are relevant: "Modernization of the mechanism of legal regulation - is the actual problem. The paradigm of this modernization allows restructuring existing law enforcement and requires innovative changes in the industry, allowing us to differentiate the study of the criminal law in the planes of the necessary legal dogmatics, expression of the legal values strategy, improvement of law enforcement" (Mizanbaev, 2012, c. 92-93). 
It is obvious that in the next calendar year, the work on reformatting regulatory decisions of the Supreme Court on compliance with the new edition of the Criminal Code will begin. And in this context, clarifications on the qualification of the crimes related to human trafficking and their differentiation are relevant.

As it was stated in the Note on the regulatory resolution of the Supreme Court of Kazakhstan on the application of criminal legislation on human trafficking by courts. In particular it was written: In part 15 of the Regulatory Resolution, it is stressed that human trafficking shall be distinguished from other crimes, e.g. Articles 113, 125, 126, 132-1, 133 and 270 of the Criminal Code. The way in which these provisions shall be distinguished should be made clearer in the Regulatory Resolution (Note on the regulatory resolution, 2012, p. 9).

In general, this document under the absence of a full-fledged basic law accordingly bears its functional load and needs to be transformed into an act of expanded judicial interpretation. Although, for the sake of fairness, it should be a temporary measure, but there is still a need for the special basic law. At the same time interesting and useful provisions are included into several documents of the United nations office on drugs and Crime, namely in "Combating trafficking in Persons, A Handbook for Parliamentarians; Needs Assessment Toolkit on the Criminal Justice Response to Human Trafficking, United Nations Office on Drugs and Crime Vienna United Nations, New York, 2010; "Model Law against Trafficking in Persons" UNITED NATIONS OFFICE ON DRUGS AND CRIME, UNITED NATIONS Vienna, 2009.

The UN recommendation Parliamentarians must have a firm understanding of the concept of trafficking in persons if they are to develop and implement effective national legislation to combat the phenomenon (Combating trafficking in Persons, 2009, p. 12) is relevant.

In conclusion we would like to draw attention to a number of issues related to the need for further improvement of the criminal law on liability for human trafficking.

Thus, in current conditions, human trafficking is conventionally divided into internal (within one state) and external ("live goods" supply to foreign countries). The latter form is an integral part of transnational organized crime. This fact is not reflected in the above normative decree of the Supreme Court, though to be fair it should be noted that this is primarily a legislative gap, as in neither art. 128 of the Criminal Code nor in art.133 of the Criminal Code there is no corresponding qualifying feature.

It would be advisable to provide measures of the compromise, namely to include a provision on the possibility of exemption from liability as a result of good behavior of a post-guilty.

Lack of rules on the use of slave labor should be regarded as another flaw, and it is despite the fact that there is every reason to criminalize the act.

In conclusion of examining the basic law in the field of combating human trafficking. We have repeatedly pointed out this aspect in a number of our works.

Almost 15 years have passed after the adoption of the UN Convention against Transnational Organized Crime in 2000 , and the next step after the ratification of the above document is the adoption of a special law on combating human trafficking. We emphasize the adoption of a namely special basic law, not the law on introducing amendments to various laws and regulations, including the Criminal Code. For example, anti-criminal basic laws on combating terrorism and extremism, narcotics, corruption, that is, those areas that have long become inter-related components of organized and even transnational crime. All of them are also united by the fact that the object of their regulation is a certain system of criminal acts, which is referred to as a kind of crime in the criminological science. It is logical that the difficult group - a conglomeration of "human trafficking" hardly fits into a simple legislative formula in the framework of the criminal law disposition. Especially, there are two of them in Kazakhstan: art. 128 and art.133 of the Criminal Code. Secondly, and this is proved by the practice of specialists in various fields and by ordinary people with the help of mass media as well, human trafficking is not only associated with buying and selling, recruiting and so on through the list of the corresponding protocol of the UN Convention against Transnational Organized Crime.

The problem of providing an adequate level of criminological security of the society is becoming more and more acute, within this security elaboration of an optimal guarantee and protection of the rights of human trafficking victims is carried out. In this regard the words of Yuri Fedotov are relevant: Human trafficking requires a forceful response founded on the assistance and protection for victims, rigorous enforcement by the criminal justice system, a sound migration policy and firm regulation of the labour markets. Overall, the international community has the tools to confront this crime. Although much has been achieved, gaps in knowledge remain. UNODC continues to need additional information about human trafficking. We need comprehensive data about 
offenders and victims in order to assist in the development of sound policies and appropriate criminal justice responses (Global Report on Trafficking in Persons , 2012, preface, p. 1).

On the basis of the set of arguments, development and early adoption of a comprehensive law on combating human trafficking should become near-term priorities, currently the bylaws play their role. The latter, in turn, do not have such important qualities as flexibility and consistency, as well as the necessary legal power in the hierarchy of legal acts.

\section{Discussions}

Many key ideas concerning improvement of legislation in the field of combating human trafficking have been approved in various scientific forums in Kazakhstan, Russia, including the OSCE Review Conference (Astana, 2010), the Euro-Asian Law Congress (Bratislava, 2011) international conferences at the Moscow State University, Moscow State Law Academy, Saratov State Law Academy, Ural State Law Academy, within the framework of management and implementation of the socially important project commissioned by the local authorities to develop proposals to the President's Administration regarding implementation of the standards of the corresponding protocol to the UN Convention against Transnational Organized Crime. The author has published two monographs and articles in leading reviewed journals, in which he persistently and systematically grounded the main idea - the need for the special basic law and the autonomy of such direction of the anti-crime policy as combating human trafficking. So far this has not happened, that's why this direction is promising both in terms of future research and further specification of the above mentioned ideas (concept and content of the policy, tools), and in terms of its implementation, that is, accumulating experience.

\section{Conclusions}

Human trafficking is a complex multifaceted phenomenon that dialectically necessitates an integrated multidisciplinary approach of theoretical understanding of its nature and parameters. The problem of unification of doctrinal, legal and judicial interpretation of the terms "human trafficking" and "crimes related to human trafficking" and their relationships as the part (component core) and the whole (conglomerate, a generic feature of which is a focus on exploitation of people) becomes pressing.

At the international level, the United Nations developed an array of regulations and guidance documents and this process continues. The formation of a complex system of measures aimed at combating human trafficking becomes an objective law; this system should be binary, i.e. consisting of the criminal law and the special basic law. Accordingly, such direction as the policy of combating human trafficking should be allocated in the structure of the state anti-crime policy; this policy should be implemented by the subject of implementation, which will be represented by law enforcement agencies, civil society institutions, including all of the people of Kazakhstan. All this is adequate in relation to world globalization processes and relevant in relation to the latest innovations of the United Nations.

\section{References}

Analysis of the statistical data on the state of crime related to human trafficking for 2010-2012, 11 months of 2013. (n. d.). Committee on Legal Statistics and Special Records of the Prosecutor General's Office of Kazakhstan. Astana.

Bekmagambetov, A. (2012). Policy to combat human trafficking: the theoretical and legal basis. Monograph. Saarbrücken: LAP LAMBERT Academic Publishing.

Bychkova, S. (2012). Combating human trafficking: current state and problems. Law and time, 5.

Combating trafficking in Persons. (2009). A Handbook for Parliamentarians Inter-Parliamentary Union and UNODC United Nations publication. IPU ISBN: 978-92-9142-408-5, UN ISBN: 978-92-1-133665-8, \#16.

Criminal Code of the Republic of Kazakhstan \#167-I. (1997, July 16). Retrieved September 25, 2014, from http://www.legislationline.org/topics/country/21/topic/14

Global Report on Trafficking in Persons. (2012). United Nations Office on Drugs and Crime Vienna United Nations. New York.

Hughes, M. (2000). The "Natasha" Trade-The Transnational Shadow Market of Trafficking in Women. University of Rhode Island "In the Shadows: Promoting Prosperity or Undermining Stability?" Journal of International Affairs. Retrieved October 16, 2014, from http://www.owl.ru/win/research/natasha.htm

Keserovic, D. (n. d.). Head of IOM Mission in Kazakhstan and Central Asia. Retrieved October 16, 2014, from $\mathrm{http} / /$ www.iom.kz/index.php/ru/?option=com_content\&view=article\&id=1 
Kozachenko, I., \& Avdeeva, E. (2012). Pressing issues of criminal law regulation of human trafficking and use of slave labor. Criminological Journal of Baikal State university of economics and law, 4.

Mizanbaev, A. (2012, May 18). The search for a new paradigm of legal regulation modernization mechanism. Lawmaking and law enforcement paradigms of criminal law reconstruction: national and international modelling experience. Collective monograph (based on the materials of the International scientific-practical seminar, Kostanai, May 18, 2012). Kostanay.

Model Law against Trafficking in Persons. (2009). United Nations Office on Drugs and Crime United Nations, Vienna.

Needs Assessment Toolkit on the Criminal Justice Response to Human Trafficking United Nations Office on Drugs and Crime Vienna United Nations. (2010). New York.

Normative Resolution of the Supreme Court of the Republic of Kazakhstan \#7 "On application of legislation determining liability for trafficking in human beings". (2012, December 29). Retrieved October 16, 2014, from http://www.legislationline.org/topics/country/21/topic/14

Note on the regulatory resolution of the Supreme Court of Kazakhstan on the application of criminal legislation on human trafficking by courts. (2012). Warsaw: OSCE, ODIHR.

On action plan of the government of the Republic of Kazakhstan for 2012-2014 directed at combatting and preventing crimes related to trafficking in human beings Decree \#1347 of the government of the Republic of Kazakhstan. With the aim. (2012, October 24). Retrieved October 16, 2014, from $\mathrm{http}: / / \mathrm{www}$. legislationline.org/topics/country/21/topic/14.

Press Release at the meeting of the Coordinating Council on identifying crimes related to human trafficking, Astana. (2013, April 29). Retrieved August 22, 2014, from http://prokuror.gov.kz/rus/novosti/press-releasy/ press-reliz-o-zasedanii-koordinacionnogo-soveta-po-voprosam-vyyavleniya/

Review of court practice (including the practice of sentencing) in criminal cases involving offenses against families and minors. (2013). Bulletin of the Supreme Court of the Republic Kazahstan, 12.

Siddharth, K. (2009). Sex trafficking inside the business of modern slavery. Columbia University press.

Source: Informational system Paragraph. (n. d.). Retrieved October 16, 2014, from http://online.zakon.kz

\section{Note}

Note 1. In 2006, the Article 128 of the Criminal Code was reconstructed and became a more full-fledged norm that meets international standards of the United Nations, in 2013 it again underwent modernization, i.e. we see a progress. However, this is not the limit.

\section{Copyrights}

Copyright for this article is retained by the author(s), with first publication rights granted to the journal.

This is an open-access article distributed under the terms and conditions of the Creative Commons Attribution license (http://creativecommons.org/licenses/by/3.0/). 